\title{
Editorial
}

\section{ON THE LISSABON-URTEIL: DEMOCRACY AND A DEMOCRATIC PARADOX}

'Oh no, not again', one of our editorial board members exclaimed in our meeting in July. 'I really do hope that we will not spend the next ten years discussing the Lissabon-Urteil, as we did with the Maastricht-Urteil.' But by all odds we will. There simply is no way around the Bundesverfassungsgericht's judgment on the Treaty of Lisbon.

No one will have missed that the German constitutional court on 30 June 2009 dismissed all constitutional complaints against the German Act Approving the Treaty of Lisbon. Nevertheless, it forbade Germany to ratify the Treaty until the Act Extending and Strengthening the Rights of the Bundestag and the Bundesrat in European Union Matters was adapted to German constitutional requirements. According to the court, the German Parliament had not reserved for itself sufficient participation powers in a variety of simplified Treaty amendment procedures, as well as the use of the so-called flexibility clause. In the meantime, the Act has been adapted and the Treaty ratified, paving the way for the Treaty's entering into force on the first of December 2009.

However, the consequences of the judgment are not restricted to these immediate effects. For several reasons the judgment will remain on the agenda of European law and scholarship for years to come, if not longer.

First of all, the judgment is relevant for the development of the Union under the Lisbon Treaty itself. In line with earlier case-law but more prominently this time, the court establishes its power to conduct an ultra vires review and an identity review on secondary Union acts. If Union acts have no foundation in competences transferred by Germany or violate the German constitutional identity as embodied in Article 79(3) Grundgesetz, the court will declare them inapplicable in Germany. ${ }^{1}$ The court also names five areas which are 'especially sensitive for the ability of a constitutional state to democratically shape itself and in which there is a particular risk of ultra vires or constitutional identity-encroaching acts: substantive and formal criminal law; the use of force by the police and the military; the fundamental fiscal decisions; decisions concerning welfare; and decisions with a par-

\footnotetext{
${ }^{1}$ See on a possible upcoming Greek constitutional identity control by the Greek Council of State, the Michaniki case note by Vasiliki Kosta in this issue.
} 
ticular cultural importance, such as those regarding family law, the school and the education system. Moreover, the court advises the German Parliament to introduce a special procedure to facilitate the court's exercise of both kinds of review. Even if this wish is not fulfilled (and more generally, as Dieter Grimm suggests in this issue, it is not the court's intention to bring the Union, in Christian Calliess' words, '[u]nter Karlsruher Totalaufsicht ${ }^{2}$ ) the Union institutions, including the Court of Justice, will have to cast a sidelong glance at the Lissabon-Urteil when acting. They will have to restrain themselves when interpreting the Union's competences if they do not want to run the risk of getting rapped on the knuckles by the Bundesverfassungsgericht.

A second reason for its persistent relevance is that the Lissabon-Urteil will influence the conclusion of future Union Treaties and affect the finality of the integration process. The court's reasoning seems to imply that the Treaty of Lisbon is more or less the terminus of European integration. On the one hand, the court does not seem to allow for a resolution of the EU's democratic deficits lest the EU become a state. On the other hand, the delineation of the core of more or less exclusive national state powers leaves very limited room for new transfers of competence. And certainly the Grundgeset\%, according to the court, stands in the way of the European Union becoming a federal state. While the court does not totally rule out that the Union will ever get there, it requires a vote of the German people itself - a vote of their representatives is not sufficient.

Third, the judgment holds the most elaborate and explicit view on the relationship between European Union law and national constitutional law that any national constitutional court has given so far, including the Bundesverfassungsgericht itself in its earlier case-law. It will therefore be compulsory reading for European law and constitutional law students alike. Moreover, the ruling, which at times reads more as an 'academic' or 'treatise text on constitutional law than a judgment', ${ }^{3}$ is so long and complex, and can be studied from so many different angles, that scholarly exegesis and debate can thrive on it for years to come.

The judgment immediately elicited a flood of reactions. In order to reduce the potential of a Justizkonflikt, which they fear is what the Bundesverfassungsgericht is heading for, and to promote the famous 'dialogue' between the German court and the Court of Justice, more than thirty German university professors, lawyers and judges have urged in a petition for the insertion of a new clause in the Act on the Bundesverfassungsgericht. It would oblige the German court to do something which it has refused to do until now: ask preliminary questions to the Court of Justice

${ }^{2}$ Christian Calliess, Frankfurter Allgemeine Zeitung, 27 Aug. 2009.

${ }^{3}$ Editorial comments: 'Karlsruhe has spoken: "Yes" to the Lisbon Treaty, but...', CML Rev (2009), p. 1023 (1023, 1033). 
when it has to decide on the interpretation of primary Union law or the interpretation and validity of secondary Union Law. ${ }^{4}$

More generally, most scholarly reactions have been very critical, with overtones of disappointment, irritation and even almost unrestrained anger, all expressed in a title of an article by Daniel Halberstam and Christoph Möllers in the German Law Journal: 'The German Constitutional Court says "ja zu Deutschland!". 5 Even several months later the disappointment remains, as several contributions in this issue testify. To name just a few points of critique: the judgment is marred by factual and conceptual inaccuracies ${ }^{6}$ and marked by a black-and-white reasoning which, as Tobias Lock in this issue asserts, does no justice to the complex reality (and perhaps even contains a twist of intellectual dishonesty). The court is also criticised for its apparent glorification of national democracy and the absence of recognition of the importance of the European integration process to the good functioning of the national democracies. As Roland Bieber so eloquently advances in this issue, taking self-determination of individuals, the rule of law and fundamental rights seriously implies that any entity must refrain from considering itself as an absolute and exclusive polity. Moreover, Martin Nettesheim and Christoph Schönberger have accused the court of what the former calls incapacitating politics', by denying the German Parliament even in its constitution-amending capacity the right to cede to the Union competences related to the constitutional identity of Germany, not to mention Germany's sovereignty. ${ }^{7}$ Paradoxically, in apparent contrast to the second Lisbon decision of the Czech Constitutional Court of 3 November 2009 (see in this issue Jan Komárek's translation of the relevant considerations), the Bundesverfassungsgericht confronts German and European representative democracy with an insurmountable national obstacle in the name of democracy.

At the same time, it cannot be denied that the court's analysis of the democratic deficiencies of Union politics touches a sore spot. We fully agree with Grimm's analysis of the fundamental distortion of the relationship between law and politics in the Union, due among other things to the elevation to constitutional (Treaty) law of many policy fields which in the member states' systems merely belong to ordinary law (and thus can be changed by the ordinary legisla-

${ }^{4}<$ www.whi-berlin.de/documents/whi-material0109.pdf>: 'Ist in einem Verfahren vor dem Bundesverfassungsgericht die Auslegung der vertraglichen Grundlagen der Europäischen Union oder die Gültigkeit und die Auslegung der Handlungen der Organe, Einrichtungen oder sonstigen Stellen der Europäischen Union entscheidungserheblich, ist das Bundesverfassungsgericht zur Vorlage dieser Frage an den Gerichtshof der Europäischen Union verpflichtet'.

${ }^{5}$ German Law Journal, No. 8, p. 1241; see also Christoph Schönberger, 'Lisbon in Karlsruhe: Maastricht's Epigones At Sea', idem, p. 1201.

${ }^{6}$ See Schönberger, supra n. 5; Halberstam \& Möllers, idem.

${ }^{7}$ Martin Nettesheim, 'Entmündigung der Politik', Frankfurter Allgemeine Zeitung, 27 Aug. 2009; Calliess, supra n. 2. 
ture). Besides this, the Union's political process is extremely difficult to follow, even for the initiated. It is very much the case, as the German court adduces, that Union politics is not based on a clear division between a governing majority and a parliamentary opposition helping to make political alternatives visible for voters at European elections, as a full-blown European public opinion would do. The unremitting inclination of national politicians to scapegoat the Union for decisions which they themselves have helped to shape only further obscures matters. In fact so much so that one is even tempted to think that it is this muddiness of European politics that is actually at the heart of the court's democratic concerns, and not the emphasis it also places on the lack of adherence to the 'one man, one vote' principle in the elections for the European Parliament. Nonetheless, the latter does pose a genuine democratic problem for an institution that according to the Lisbon Treaty is supposed to represent the Union citizens, if one of its members represents approximately 857.000 citizens (a German MEP), another 630.000 (a Dutch MEP) and a third 67.000 (a Maltese MEP). Certainly one of the points that will be discussed in academia in the next decade is how this form of 'degressive proportionality' in the representation by the European Parliament, which cannot be expected to change, can be reconciled with our traditional ideas of political representation and the respect for the principle of equality promised to Union citizens by Article 9 of the Union Treaty.

But for the moment, who would deny that there is a loss of transparency, democratic accountability and electoral equality for German voters if competences are exercised by the Union rather than by German institutions? And aside from the legal merits of the judgment under German constitutional law: who cannot at least understand why the court, in the name of democracy, objects to the Union taking fundamental decisions on substantive and formal criminal law, on the employment of police and military forces, on the budget, on the welfare state, on family law and the school and education system and so forth in Germany, given the Union's present democratic state of affairs?

The Bundesverfassungsgericht was castigated for the Maastricht-Urteil by most European lawyers, especially the Germans among them. But that judgment has placed its stamp on much of the constitutional development of the Union and has allowed theories of constitutional pluralism, polycentrism, multilevel constitutionalism, Verfassungsverbund and the constitution composée to flourish. The German constitutional court is likewise being castigated for its Lissabon-Urteil. Certainly, it has put the questions of democracy, the level at which democracy is to be aggregated and articulated, and the pertaining institutional arrangements in the member states and in the Union higher on the agenda of intellectual and political engagement than they have been over the last decades. Perhaps it will be just as fruitful for European constitutional theory as the Maastricht-Urteil was. 